\title{
Oceanic adults, coastal juveniles: tracking the habitat use of whale sharks off the Pacific coast of Mexico
}

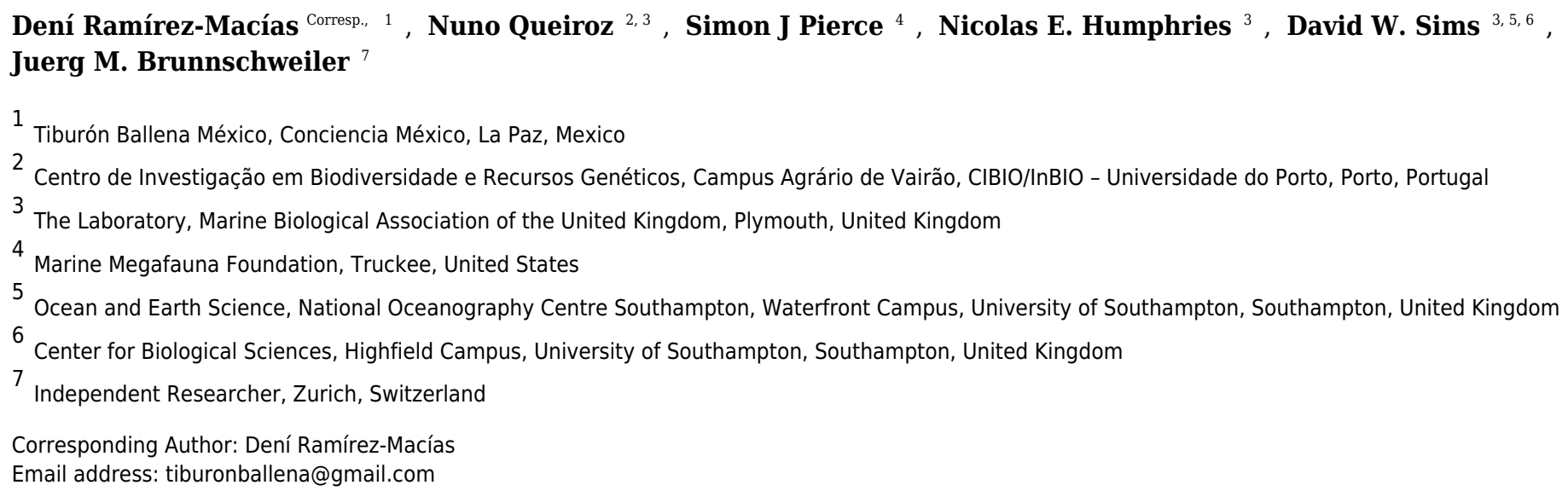

Eight whale sharks tagged with pop-up satellite archival tags off the Gulf of California, Mexico, were tracked for periods of 14-134 days. Five of these sharks were adults, with four females visually assessed to be pregnant. At least for the periods they were tracked, juveniles remained in the Gulf of California while adults moved offshore into the eastern Pacific Ocean. We propose that parturition occurs in these offshore waters. Excluding two juveniles that remained in the shallow tagging area for the duration of tracking, all sharks spent $65 \pm 20.7 \%$ (SD) of their time near the surface, even over deep water, often in association with frontal zones characterized by cool-water upwelling. While these six sharks all made dives into the meso- or bathypelagic zones, with two sharks reaching the maximum depth recordable by the tags ( $1285.8 \mathrm{~m}$ ), time spent at these depths represented a small proportion of the overall tracks. Most deep dives (72.7\%) took place during the day, particularly during the early morning and late afternoon. Pronounced habitat differences by ontogenetic stage suggest that adult whale sharks are less likely to frequent coastal waters after the onset of maturity. 
1 Oceanic adults, coastal juveniles: tracking the habitat use of whale sharks off the Pacific 2 coast of Mexico

3

4 Dení Ramírez-Macías ${ }^{1,{ }^{*}}$, Nuno Queiroz ${ }^{2,3 \#}$, Simon J. Pierce ${ }^{4}$, Nicolas E. Humphries ${ }^{3}$, David W. 5 Sims $^{3,5,6}$ and Juerg M. Brunnschweiler ${ }^{7 \#}$

$7 \quad{ }^{1}$ Tiburón Ballena México, Conciencia México, La Paz, Mexico

8

9 '2entro de Investigação em Biodiversidade e Recursos Genéticos, Campus Agrário de Vairão, CIBIO/InBIO - Universidade do Porto, Porto, Portugal

11

${ }^{3}$ The Laboratory, Marine Biological Association of the United Kingdom, Plymouth, United Kingdom

${ }^{4}$ Marine Megafauna Foundation, Truckee, United States

${ }^{5}$ Ocean and Earth Science, National Oceanography Centre Southampton, Waterfront Campus, University of Southampton, Southampton, United Kingdom

${ }^{6}$ Centre for Biological Sciences, Highfield Campus, University of Southampton, Southampton, United Kingdom

${ }^{7}$ Independent Researcher, Zurich, Switzerland

\#These authors contributed equally and share the senior authorship

*Corresponding author

Address: Alvaro Obregon 2140 int 110 Col Centro La Paz BCS, CP 23000. Mexico

Phone: +526121296975

e-mail: tiburonballena@gmail.com 
Abstract Eight whale sharks tagged with pop-up satellite archival tags off the Gulf of California, Mexico, were tracked for periods of 14-134 days. Five of these sharks were adults, with four females visually assessed to be pregnant. At least for the periods they were tracked, juveniles remained in the Gulf of California while adults moved offshore into the eastern Pacific Ocean. We propose that parturition occurs in these offshore waters. Excluding two juveniles that remained in the shallow tagging area for the duration of tracking, all sharks spent $65 \pm 20.7 \%$ (SD) of their time near the surface, even over deep water, often in association with frontal zones characterized by cool-water upwelling. While these six sharks all made dives into the meso- or bathypelagic zones, with two sharks reaching the maximum depth recordable by the tags (1285.8 $\mathrm{m})$, time spent at these depths represented a small proportion of the overall tracks. Most deep dives $(72.7 \%)$ took place during the day, particularly during the early morning and late afternoon. Pronounced habitat differences by ontogenetic stage suggest that adult whale sharks are less likely to frequent coastal waters after the onset of maturity.

\section{Introduction}

Electronic tagging studies have revolutionised our understanding of the behaviour and spatial ecology of marine animals. Linking these movement data to key environmental processes has led to critical insights into the movements of highly migratory marine vertebrates (Pade et al., 2009; Robinson et al., 2009; Block et al., 2011). This has supported the conservation of such species by provision of new information on where they range, which habitats are critical, what behaviours they perform, and why they may do so (Sims, 2010).

Whale sharks are highly mobile, with their movements driven by environmental conditions and associated biological productivity (Sequeira et al., 2013). Satellite tagging, in conjunction with remote sensing data, can be used to infer the influence of highly productive pelagic areas on the movement of these animals. Use of surface frontal zones in the open ocean represents a successful strategy to maximise prey encounter rates in patchy offshore seascapes, and has 
62 previously been documented in planktivorous sharks (Miller et al., 2015) and other pelagic shark 63 species (Queiroz et al., 2016).

64

Most whale shark studies have taken place at their coastal feeding aggregations, where they typically exploit an ephemeral abundance of plankton or nekton in surface waters (Clark \& Nelson, 1997; Ketchum, Galván-Magaña \& Klimley, 2013; Robinson et al., 2013; Rohner et al., 2015a). Whale sharks also make deep dives, to a maximum-recorded depth of $1,888 \mathrm{~m}$ (Hueter, Tyminski \& de la Parra, 2013), and appear to use meso- and bathypelagic depths regularly (Brunnschweiler et al., 2009). However, in almost all of the coastal locations where they are routinely sighted, the majority of sharks present are juvenile males (Rohner et al., 2015b). Few data are available for other ontogenetic stages (Rowat \& Brooks, 2012), with the exception of large females tagged at Darwin Island in the Galapagos Islands, Ecuador (Hearn et al., 2016), and previously off the Baja Californian peninsula (Eckert \& Stewart, 2001).

Whale sharks have been globally impacted by human activities, leading to an Endangered listing on the IUCN Red List (Pierce \& Norman, 2016) and inclusion on Appendices II of both the Convention on International Trade in Endangered Species (CITES) and the Bonn Convention for the Conservation of Migratory Species of Wild Animals (CMS). The lack of information on whale shark habitat use is a significant knowledge gap, particularly with respect to the rare occurrence of the different ontogenetic stages and sexes within the same habitat or area. Frontal zones are effectively targeted by fisheries, which makes the study of pelagic movements in threatened species, like the whale shark, particularly relevant (Queiroz et al., 2016).

The Gulf of California (GoC) is a semi-enclosed sea known for its high biodiversity and primary production (Wilkinson et al., 2009). Globally, it is one of the only areas from which immature whale sharks, of both sexes, and large mature females have been routinely recorded (Clark \& Nelson, 1997; Eckert \& Stewart, 2001; Ramírez-Macías et al., 2007; Ramírez-Macías, VázquezHaikin \& Vázquez-Juárez, 2012; Ketchum, Galván-Magaña \& Klimley, 2013; Cochran et al., 2016). Some of the few reported neonatal whale sharks have also been found in this region (Wolfson, 1983). Together this identifies the region as one of only a few locations globally 
92 where the movements and habitat use of adult and juvenile whale sharks can be readily

93 investigated in response to similar environmental factors.

94

95

96

97

98

99

100

101

102

103

104

105

106

107

108

109

110

111

112

113

114

115

116

117

118

119

120

121

122

Here, we used pop-off satellite-linked archival transmitter (PSAT) tags to examine the habitat use of whale sharks from the GoC, with a particular focus on adult sharks. In the only previous satellite tagging study on whale sharks from the GoC, Eckert \& Stewart (2001) tracked adult females moving into the deep waters of the eastern Pacific Ocean. Our specific aims in the present study were to (i) determine if adult whale sharks are transient in the GoC, (ii) identify if juvenile whale sharks use different habitats compared to adult whale sharks, and (iii) investigate the influence of open-ocean frontal systems on their space use. Our results provide some of the first insights into the detailed horizontal and vertical movements of adult whale sharks, and provide information on the spatial ecology and behaviour of this threatened species in the eastern Pacific Ocean.

\section{Materials \& Methods}

This research was carried out under the general auspices of CONACYT (Consejo Nacional de Ciencia y Tecnología), DGVS (Dirección General de Vida Silvestre), SEMARNAT (Secretaría del Medio Ambiente y Recursos Naturales) and CONANP (Comisión Natural de Áreas Naturales

Protegidas). These are the relevant Mexican authorities governing all research actions on wildlife and protected animals and areas in Mexico. CONACYT registration: RENIECYT No. 030 (currently 1602199) and 13920. DGVS authorization numbers are: SGPA/DGVS/02677/08, SGPA/DGVS/02888/09, SGPA/DGVS/03848/10, SGPA/DGVS/03155/11, SGPA/DGVS/03362/12.

\section{Study site and electronic tagging}

Seventeen whale sharks, ranging from 5 to $12 \mathrm{~m}$ total length, were tagged with PSATs (PTT-100 standard rate PSAT; Microwave Telemetry Inc.): 16 between 2008 and 2011, in inshore waters of Bahía de La Paz, the marine protected area (MPA) of Espíritu Santo Island (ESI), and a single individual at Banco Gordo in 2012 (Fig. 1A; Table 1). A spotter airplane was used to locate 
123 sharks off ESI. Flights followed pre-defined transects over a duration of three hours. The east

124 and west coasts of ESI (including El Bajo), respectively, were covered over consecutive days.

125 Surveys were conducted weekly in May 2009 and from May to July in 2010. Whale shark

126 positions were communicated to the research vessel $(7 \mathrm{~m})$ via radio, allowing the vessel to

127 conduct in-water studies. Shark lengths were measured by a swimmer using a metric band or

128 estimated by repeated on-board observations of the whale shark swimming parallel to the

129 research vessel (Ramírez-Macías, Vázquez-Haikin \& Vázquez-Juárez, 2012; Fig. S1A). Sex of

130 the animal was determined by the presence of claspers on males, which are visible from birth.

131 Clasper morphology was used to distinguish juvenile from adult males: claspers are short, soft,

132 and smooth in sexually immature males, but quickly grow and calcify during maturation

133 (Norman \& Stevens, 2007). Females were categorized as either juvenile or adult based on their

134 estimated lengths and external indications of pregnancy (i.e. distended abdomen; Ramírez-

135 Macías, Vázquez-Haikin \& Vázquez-Juárez, 2012; Acuña-Marrero et al., 2014; Robinson et al.,

136 2016). While we acknowledge the difficulty of confirming pregnancy in adult female sharks, the

137 visual assessments made for the present study were based on extensive field observations of

138 adult sharks, both pregnant and non-pregnant, by the first author (Ramírez-Macías, Vázquez-

139 Haikin \& Vázquez-Juárez, 2012). Given the uniquely distended nature of the pelvic region in

140 these sharks, pregnancy seems to be the most parsimonious explanation. However, given that

141 pregnancy was not possible to verify by direct methods (e.g. ultrasonography) we refer to

142 putative pregnancy in whale sharks in this study. We have proceeded on that assumption. The

143 flank of each whale shark was also photographed for individual identification (Marshall \&

144 Pierce, 2012; Ramírez-Macías, Vázquez-Haikin \& Vázquez-Juárez, 2012).

145

146 Whale sharks were tagged using a spear gun with a standard rubber band. The full tag setup

147 consisted of the PSAT unit, a $136 \mathrm{~kg}$ test monofilament tether and a stainless steel tag anchor.

148 All whale sharks were tagged on the left side at the base of the first dorsal fin. Tags were

149 programmed to pop off after deployment intervals of either 9 (274 days) or 12 (365 days) months

150 (Table 1). During deployment on the study animal, Microwave Telemetry's standard rate PSATs

151 record temperature, depth and light-level every 2 minutes (for a detailed description on how

152 PTT-100 standard rate PSATs record, archive and transmit data see Brunnschweiler (2014) and

153 http://www.microwavetelemetry.com/fish). The maximum depth the tag model used in this study 
154 can archive is $1285.7 \mathrm{~m}$. However, an emergency release feature detaches the tag automatically

155 when the shark is deeper than $\sim 1250 \mathrm{~m}$ for more than 15 min to prevent the tag from being 156 crushed at depth. In all tags attached to adult whale sharks, and juveniles JM1 and JM2 (Table

157 1), a constant pressure release feature, set at $\pm 10 \mathrm{~m}$ for 4 days, was enabled (Brunnschweiler et 158 al., 2009; Brunnschweiler, Queiroz \& Sims, 2010). In all other tags attached to juvenile whale 159 sharks (Table 1), the constant pressure release feature was set at $\pm 3 \mathrm{~m}$ for 4 days.

160

161

Data analysis

162

163

164

Eight of the 17 PSATs attached to whale sharks (47.1\%) uplinked to the Argos satellite system and transmitted data (Table 1). Pop-off date and the reasons for detachment were determined by constant $0 \mathrm{~m}$ depth readings, start time of transmission to the Argos satellite system, and status

166

167

168

169

170

171

172

173

174

175

176

177

178

179

180

181

182

183

184 information transmitted by the PSAT. After pop-off, PSATs AF2, AF3 and AF4 each floated on the surface for several days $(6,10$, and 10 respectively) before uplink to the Argos satellites, and therefore true pop-off positions are unknown.

Whale shark locations were estimated using satellite-relayed data from each tag. Recovered light-level data were used by Microwave Telemetry (MT) to estimate local time of midnight or midday for longitude calculations and day length for latitude calculations using a proprietary algorithm derived from standard celestial algorithms. Light-derived position estimates were subsequently improved by combining: (i) a swim speed filter (to constrain distances); (ii) remotely sensed SST data and tag recorded SST values to constrain probable locations; and (iii) location bathymetry and tag recorded depths to filter positions that would be too shallow. To achieve this, the MT-estimated latitudinal and longitudinal positions and error fields were used to define the area that contained all the possible positions for a given location. A $1 \mathrm{~m} \mathrm{~s}^{-1}$ swimspeed filter [which is consistent with cruise speeds of pelagic sharks (Gunn et al., 1999; Sims, 2000)] was used for each estimated position to generate a circular area representing the possible positions that could be reached by the shark in the time between the current and the next location estimate. The intersection of the swim speed area and the error field produced a sub-set of possible points which were then filtered to ensure the maximum dive depth did not exceed that possible given the bathymetry at that location. All the available filtered points were then checked 
185

186

187

188

189

190

191

192

193

194

195

196

197

198

199

200

201

202

203

204

205

206

207

208

209

210

211

212

213

214

215

against the corresponding SST map (using OSTIA high-resolution, spatially complete, global coverage remote-sensing images) for that day and any points within a $2^{\circ} \mathrm{C}$ threshold between the tag-recorded temperature and the SST were recorded as possible 'waypoints'. After all locations were processed, the waypoints at each location were scored according to the difference in SST and distance from the original estimated location with high scores representing poorer SST matches and longer distances. The best (lowest) scoring waypoints were then connected to form a most probable track. Resighting data were also used when available by fitting them as known locations during the filtering process and these were incorporated into the final tracks.

Gaps between consecutive dates were linearly interpolated to one position per day to obtain unbiased estimates of shark space use. Furthermore, to account for the spatial error around individual geolocations, these were randomly resampled 100 times (point density data) along previously reported tag-specific longitudinal and latitudinal Gaussian error fields; $0.16^{\circ}$ in longitude and $1.19^{\circ}$ in latitude (Hueter, Tyminski \& de la Parra, 2013; Fig. S2). Resampled geolocations were then combined with satellite-derived environmental data; the environmental data used were daily (i) sea surface temperature, SST and from NOAA Optimum Interpolation Quarter Degree Daily SST Analysis (OISST) data. Based on the OISST data we also calculated (ii) daily SST maximum gradient maps by calculating, for each pixel, a geodetic-distancecorrected maximum thermal gradient $\left({ }^{\circ} \mathrm{C} / 100 \mathrm{~km}\right.$ ), and (iii) monthly merged chlorophyll $a$ levels $\left(0.25^{\circ}\right.$ spatial resolution), acquired from GlobColour (European Space Agency - ESA). Before further analysis, point density and environmental data were averaged into $0.5^{\circ}$ grid cells (Fig. S3).

Point density data were used to calculate shark space use by performing a kernel density interpolation with barriers in ESRI ArcGIS [v. 10.3]. To analyse the spatial relationship between environmental variables and shark space-use, a Generalized Linear Mixed Model (GLMM) analysis with penalized Quasi-Likelihood parameter estimation (PQL; to account for non-normal error distributions) was employed using R (Venables \& Ripley, 2002; Austin et al., 2006). In the model, shark space-use was set as a random factor, while environmental parameters were set as fixed effect factors. An autocorrelation structure of order 1 (corAR1) was used to account for the temporal correlation in the dataset (Zuur et al., 2009). GLMM models were fitted with a normal 
216 (Gaussian family) distribution. Finally, to evaluate model performance, the concordance index

217 (C-index; Harrell et al., 1984) was calculated using R (Hmisc package). The C-index estimates

218 the probability of concordance between predicted and observed responses, varying between 0.5

219 and 1.0 with the following classification: excellent if above 0.9; good 0.9-0.8; reasonable 0.8-

220 0.7; poor 0.7-0.6 and unsuccessful 0.6-0.5 (Swets, 1988). Model results are given in the

221 following format: $\beta \pm \mathrm{SD}, \mathrm{P}, \mathrm{C}$-index, where $\beta$ is a measure of the slope of the relationship.

222 Presence of sharks in 'coastal' waters is defined here as continental shelf $(<200 \mathrm{~m})$, while

223 'offshore' refers to the open ocean (>200 m depth).

224

225 Vertical movements and diel patterns in behaviour were analyzed for individual whale sharks

226 using archived time-depth and time-temperature data (depth and temperature resolution $=\sim 5.4 \mathrm{~m}$

227 and $\sim 0.17^{\circ} \mathrm{C}$, respectively). Due to the non-Gaussian distribution of the data, mean and median

228 were used to summarize the results, and the nonparametric Mann-Whitney U test for

229 comparisons (significance level =0.05). Except for the analysis of deep dives (see below), delta

230 limited depth and temperature values (Brunnschweiler, 2014) were removed from the raw

231 datasets, with mean and medians used to summarize the results. Vertical and thermal niches were

232 determined using daily minimum/maximum depth and temperature values recorded at 2 minute

233 intervals (Brunnschweiler, 2014).

234

235

Archived and daily minimum/maximum depth readings were assigned to one of three categories:

236 epipelagic $(0 \mathrm{~m},<200 \mathrm{~m})$, mesopelagic $(>200 \mathrm{~m},<1000 \mathrm{~m})$ and bathypelagic $(>1000 \mathrm{~m})$.

237 Pressure readings of 0 and $5.4 \mathrm{~m}$ were defined as the whale shark being at the water surface

238 (Brunnschweiler \& Sims, 2012) and deep diving was defined as diving to meso- or bathypelagic

239 depths. To investigate at what time(s) of the day deep diving occurred, all archived depth

240 readings including delta limited values in the meso- or bathypelagic zones were assigned to one

241 of 24 hourly bins. An individual deep dive was defined as the time between the whale shark

242 descending from $<50 \mathrm{~m}$ to meso- or bathypelagic depths until reaching the surface again. The

243 time-depth series (archived depth values at 15 minute intervals) of individual deep dives with

244 maximum non-delta limited archived depth recordings in the meso- and bathypelagic zones were

245 plotted, visually classified based on their time-depth profiles, and their dive geometry

246 characterised following definitions provided by Gleiss, Norman \& Wilson (2011). To test the 
247 hypothesis that deeper dives (maximum daily depth) occurred in less productive waters, a

248 Spearman Rank correlation was performed (data not normally distributed; Shapiro-Wilk; W = $2490.588, \mathrm{p}<0.001$ ) between maximum daily depth (using pooled data for all tracked whale sharks) 250 and mean chlorophyll- $a$ concentration.

251

252

253

254

255

256

257

258

259

260

261

262

263

264

265

266

267

268

269

270

271

272 273

274

275

276

277

\section{Results}

Resightings and tag performance

All eight PSATs prematurely detached from sharks after being attached for 14-134 days (Table 1). Of these, four (JM1, AF1, AF2, JM2) and two (JF1, AM1) PSATs released due to activation of the constant pressure or the crush depth emergency release mechanisms, respectively. For two PSATs (AF3, AF4), the reason for premature release was unknown (Table 1). Except for PSAT AF2, for which three days were missing, latitude and longitude positions were transmitted for all days of the respective tracks. PSATs transmitted between 30 and 100\% of archived pressure and temperature data (Table 1). Data from six PSATs (AF1, AF2, JF1, AF3, AM1, AF4) contained between 0.1 (AF2) and 2\% (AM1), and 2.5 (JF1) and 23.2\% (AM1) delta limited depth and temperature values, respectively.

Eight whale sharks were resighted post-tagging using photo-identification (Table 2). Six of them were resighted in the coastal waters of Bahía de La Paz (Fig. 1A). Two whale sharks were resighted away from the tagging site. The juvenile male tagged in Bahía de La Paz on 16 February 2011 was resighted, without the PSAT, in the protected area of Bahía de Los Angeles on 13 August 2011. The pregnant whale shark tagged at Banco Gordo on 8 May 2012 was resighted, without the tag, in the protected area of Roca Partida, the smallest of the four Revillagigedo Islands (Fig. 1B), on 22 November 2012, and was reported to be pregnant.

\section{Horizontal movements}

There was a marked difference in the horizontal movements exhibited by juvenile and adult whale sharks. All juveniles remained in the $\mathrm{GoC}$, while all adult animals moved out into the 
278

279

280

281

282

283

284

285

286

287

288

289

290

291

292

293

294

295

296

297

298

299

300

301

302

303

304

305

306

307

308

eastern Pacific Ocean. The two juvenile males JM1 and JM2, tagged for 25 and 14 days

respectively, remained in the shallow waters of Bahía de La Paz where they were tagged. All six other whale sharks left the tagging area and moved large distances (Fig. 1B). Tagged animals mainly occupied two areas, one in the coastal waters around the southern part of the Baja California peninsula, and the other offshore in the eastern Pacific Ocean (Fig. 2).

Juvenile JF1 spent the first weeks after tagging in and north of Bahía de La Paz before moving north to $28.7^{\circ} \mathrm{N}-113.0^{\circ} \mathrm{W}$ where the tag popped-off south of Bahía de Los Angeles, on 9 May, after 58 days (Fig. 1B). Pregnant whale sharks AF1 and AF2 both left the tagging area, and after a week the GoC, moving to the same offshore area (Fig. 1B). It appears that both animals moved clockwise in a large circle in June/July 2009 before heading north. Whereas shark AF1 lost its tag after 44 days on 6 July, shark AF2 was tracked for another three months. In that time period, it continued to move north (Fig. 1B). All three females, adults AF1 and AF2 as well as juvenile $\mathrm{JF} 1$, remained in productive waters for longer time periods before moving north.

Putative pregnant whale sharks AF3 and AF4, tagged in 2010, left the GoC shortly after tagging, similar to sharks AF1 and AF2 from 2009. The 2010 sharks remained associated with productive coastal waters in July/August, before moving to an oligotrophic offshore area in September where tags popped off (Fig. 1B). Similar to the pregnant females, the only adult male (AM1) tagged in this study left the Gulf of California within a week after tagging and quickly moved south where it stayed in a relatively confined area in August until the PSAT popped off (Fig. 1B).

GLMM analysis showed that shark space-use was significantly influenced by SST and SST gradients (fronts). However, temperature had a negative (albeit weak) effect on space-use, while stronger thermal gradients had a positive effect (Table 3 ) indicating whale sharks tended to spend more time in frontal regions linked with upwelling (which resulted in colder surface water). No significant relationship was found between shark space-use and chlorophyll $a$ concentration and model performance was reasonable $(\mathrm{C}$-index $=0.7)$.

\section{Vertical movements}


310 Mean depth and temperature experienced by individual whale sharks ranged between 1.1 (JM2)

311

312

313

314

315

316

317

318

319

320

321

322

323

324

325

326

327

328

329

330

331

332

333

334

335

336

337

338

339

and $29.4 \mathrm{~m}$ (AM1), and 21.64 (AF1) and $25.48^{\circ} \mathrm{C}$ (JM1), respectively (Table 4). Significant day and night differences in mean depth were detected in all but one individual (JM1). Mean depth was greater during the night for all sharks except for JF1, the one juvenile that moved significantly away from the tagging area, which stayed deeper during the day (Table 4).

Excluding juvenile whale sharks JM1 and JM2, which did not leave the tagging area over the duration of PSAT attachment and dived to relatively shallow maximum depths of 32.3 and 21.5 $\mathrm{m}$, respectively, time spent at the surface $(<6 \mathrm{~m})$ constituted $65 \pm 20.7 \%$ of total time for the other whale sharks. These six whale sharks, which all moved long distances from the area where they were tagged (Fig. 1B), spent most of their time in $20-26^{\circ} \mathrm{C}$ water. All exhibited regular diving throughout their tracks and had broad vertical and thermal niches. Three individuals were recorded in each of the mesopelagic (AF1, AF3, AF4) and bathypelagic (AF2, JF1, AM1) zones several times during PSAT attachment (Fig. 3). Two sharks, JF1 and AM1, recorded dives to or exceeding the maximum depth that the tags could record (1285.8 $\mathrm{m}$; Table 4$)$.

Individual differences with regards to overall diving behaviour were evident. The four putative pregnant whale sharks (AF1, AF2, AF3, AF4) that left the GoC showed similar diving patterns, with maximum daily depths in the epipelagic zones on most days (Fig. 3A, B, D, F). The juvenile whale shark (JF1) that stayed within the GoC stayed shallow with a maximum diving depth of $32.3 \mathrm{~m}$ for the first 49 days of its track, excluding 3 April 2010 (Fig. 3C). Then, for the remaining nine days before the PSAT popped up due to activation of the deep-depth release mechanism, this whale shark showed increased deep diving activity into the meso- and bathypelagic zones during its northwards movement to the upper GoC (Fig. 1B; Fig. 3C). This shark (JF1), with a mean depth of 6 m over the entire duration of the track, marked the shallowest end of the spectrum. The adult male whale shark AM1 was the individual with the deepest mean depth (Table 4). This whale shark quickly left the GoC and moved south (Fig. 1B), with daily maximum depths in the meso- and bathypelagic zones on $52.5 \%$ of days tracked (Fig. 3E). 
341

342 Overall, sharks spent a relatively small amount of time in the meso- and bathypelagic zones (Fig.

\section{Meso- and bathypelagic diving and dive geometry} 3). Dives to maximum depths in these zones occurred largely during the day, with $72.7 \%$ of all $>200 \mathrm{~m}$ recordings archived between 06:00 and 18:00 (Fig. 4). Most deep diving activity was performed in the morning between 07:00 and 09:00 (28.6\%) and in the late afternoon between 15:00 and 18:00 (20.8\%) (Fig. 4).

Fifteen dive profiles with maximum depth readings in the mesopelagic zone were available for visual classification. Nine contained delta limited depth values (Brunnschweiler, 2014). Three were characterized as isolated V-dives (Fig. 5A), two as V-dives in series (Fig. 5B), four as Udives (Fig. 5C), and six dive profiles could not be assigned to any of the geometries described by Gleiss, Norman \& Wilson (2011) because of uncertainties with delta limited data points (Fig. 5D). All 15 dive profiles indicate that whale sharks quickly dived from the epipelagic zone to the maximum mesopelagic depth and back up into surface waters after the animal spent little (e.g. Vdives) or longer time periods (U-dives) at depth (Fig. 5A-D). The pattern of rapid descents and ascents can also be inferred from the only two dive profiles that contain actual depth readings in the bathypelagic zone, but could not be reconstructed with confidence because of missing archived data points and most depth values being delta limited (Fig. 5E and F; see Brunnschweiler (2014) for details). Mean dive depth was negatively correlated with chlorophyll $a$ concentration (Spearman Rank correlation; $\mathrm{rs}=-0.16, p<0.05$ ).

\section{Discussion}

Juvenile and adult whale sharks displayed clear differences in their movement patterns. The five adult whale sharks tracked from the GoC, which included four adult females that were visually assessed to be pregnant, all moved a significant distance following tagging and spent the majority of their time in the open ocean. The females moved south and then to the north, offshore of the peninsula of Baja California, whereas the only male tracked moved straight to the south. In contrast, based on tracks and photo-identification data, juveniles showed a high degree of site fidelity to the GoC. Strong thermal gradients were positively associated with whale shark 
371 occurrence, indicating that they were spending time in frontal zones that were associated with

372 upwelling systems. Meso- and bathypelagic dives were regularly recorded from all sharks.

373

374 Size- and sex-based segregation of whale sharks has been well-documented previously within the

375 GoC area. This can be summarised as an offshore and coastal division, with adult females

376 typically found in oceanic waters around or outside the $200 \mathrm{~m}$ isobath, while juveniles are found

377 in coastal areas (Ramírez-Macías, Vázquez-Haikin \& Vázquez-Juárez, 2012). Adults,

378 specifically pregnant females, are seasonally present at Banco Gordo and Espíritu Santo Island

379 (Eckert \& Stewart, 2001; Ramírez-Macías et al., 2007; Ramírez-Macías, Vázquez-Haikin \&

380 Vázquez-Juárez, 2012; Ketchum, Galván-Magaña \& Klimley, 2013). Juvenile whale sharks have

381 been routinely observed feeding on calanoid copepods in shallow waters off Bahía de Los

382 Angeles (Nelson \& Eckert, 2007), and separately at Bahía de La Paz (Clark \& Nelson, 1997;

383 Hacohen-Domené, Galván-Magaña \& Ketchum-Mejia, 2006). Long-term photo-ID from these

384 areas, which have significant connectivity between them, found that the sharks present were

385 typically juveniles, and predominantly males (Ramírez-Macías, Vázquez-Haikin \& Vázquez-

386 Juárez, 2012). Short-term residency periods of up to 153 days were noted for individual sharks,

387 with a high level of inter-annual resightings (Ramírez-Macías, Vázquez-Haikin \& Vázquez-

388 Juárez, 2012). In the present study, all six juvenile whale sharks tagged at Bahía de La Paz

389 between 2008 and 2010 were resighted several times in the GoC, both with and without tags,

390 after days to months of tracking.

391

392 Adult sharks, particularly adult females, are conspicuous by their absence in most coastal

393 aggregations (Rowat \& Brooks, 2012; Hueter, Tyminski \& de la Parra, 2013; Rohner et al.,

394 2015b). Given the number of researchers surveying coastal areas around the world, the

395 possibility that large whale sharks are commonly using this habitat seems remote (Hueter,

396 Tyminski \& de la Parra, 2013). Dedicated surveys in some regions (Ramírez-Macías, Vázquez-

397 Haikin \& Vázquez-Juárez, 2012; Ketchum, Galván-Magaña \& Klimley, 2013; this study), and

398 observations from others (Afonso, McGinty \& Machete, 2014; Robinson et al., 2016), indicate

399 that mature whale sharks primarily inhabit offshore habitats. While the use of inshore habitats by

400 juvenile sharks has been associated with zooplankton biomass in Bahía de La Paz and Bahía de

401 Los Angeles (Hacohen-Domené, Galván-Magaña \& Ketchum-Mejia, 2006; Nelson \& Eckert, 
402

403

404

405

406

407

408

409

410

411

412

413

414

415

416

417

418

419

420

421

422

423

424

425

426

427

428

429

430

431

432

2007; Ketchum, Galván-Magaña \& Klimley, 2013), the seasonal biomass of zooplankton was not strongly correlated with adult shark presence in the outer Bahía de La Paz (Ketchum, Galván-Magaña \& Klimley, 2013). This defined segregation between adult (female) and juvenile (largely male) sharks may therefore relate to differences in behavioural strategy, possibly including a dietary shift. Based on our results, adult female whale sharks appear likely to be found associated with offshore frontal systems. This supports recent studies from the Galapagos Islands (Hearn et al., 2016) that obtained detailed movement data from adult female sharks tagged at Darwin Island in the north of the archipelago. Many of these sharks travelled westwards, correlated with the flow of the South Equatorial Current, and close to the Equatorial Front which is a known biologically productive area (Hearn et al., 2016). Planktivorous basking shark Cetorhinus maximus sightings have also been strongly associated with tidal and large-scale frontal systems in the Eastern Atlantic (Sims, 2008, Miller et al., 2015).

The regular presence of female sharks, almost exclusively pregnant, in deep waters in the southern part of the GoC suggests that their presence is related to breeding. While the gestation period of whale sharks is not known, the pregnant female tagged in May 2012 at Banco Gordo, was also pregnant when observed in the Revillagigedo Islands in November 2012. Another pregnant female was photographed at the Revillagigedo Islands in November 2012 and resighted in May 2013 at Banco Gordo (Ramírez-Macías, unpubl. data). Therefore, it is possible that pregnancy lasts seven months or longer, if the observed distensions of the abdomen in each individual whale shark were pregnancies with the same litters. Individuals are transient to areas such as Banco Gordo (Ramírez-Macías, Vázquez-Haikin \& Vázquez-Juárez, 2012; Ketchum, Galván-Magaña \& Klimley, 2013; this study) and, over the duration of tracking four pregnant females in this study (44-134 days), and three pregnant females tracked for 30-665 days by Eckert \& Stewart (2001), all spent the majority of their time offshore from the GoC. While the small sample size limits interpretation, it is possible that parturition takes place in this offshore region. A very small, free-swimming whale shark pup was sighted at Espíritu Santo Island on 4 July 2015 (Fig. S3B). Oceanic pupping has been hypothesized for Atlantic whale sharks (Hueter, Tyminski \& de la Parra, 2013), which is also supported by preliminary stable isotope profiles that suggest a transition from a pelagic offshore life of smaller $(<4 \mathrm{~m})$ whale sharks to a relatively more coastal habitat as size increased in whale sharks caught from India (Borrell et al., 
433 2011). Photo-identification data from 2003-2014 has documented one female returning to Banco

434 Gordo after seven years; the female was pregnant on both occasions (Ramírez-Macías, unpubl.

435 data). Continued research effort in this area may be rewarded with further inter-annual

436 resightings of pregnant sharks, providing valuable data on reproductive periodicity, and detailed

437 documentation of the ontogenetic habitat shift that may be a feature of this population.

438

439

Adult female whale sharks moved into the Southern California Pacific, and the single male into

the Mexican Pacific Transition. Both areas are deep eco-regions with offshore islands and seamounts (Wilkinson et al., 2009) that appear to be favoured habitats by adult whale sharks and other predators (Croll et al., 2012; Hearn et al., 2013; Afonso, McGinty \& Machete, 2014). Whale shark neonate habitat is poorly known, although they have typically been found in or close to oceanic waters (Rowat et al., 2008). Neonatal pups are thought to have limited swimming ability, so the presence of both pregnant females and very small ( $\sim 2 \mathrm{~m})$ juveniles around Bahía de La Paz, coupled with genetic evidence for natal philopatry to the GoC, suggests that pupping takes place nearby (Ramírez-Macías et al., 2007). While the oceanic area off the GoC is a noted hotspot for predatory fishes (Block et al., 2011), coastal waters within the GoC have a low observed density of potential whale shark predators and may be used as a refuge (Ramírez-Macías, Vázquez-Haikin \& Vázquez-Juárez, 2012).

451

Although the adult sharks spent their time offshore over the period of tracking, largely in bathymetrically non-constraining habitat, all the sharks spent most of their time in the top $6 \mathrm{~m}$ of water, experiencing temperatures of $20-26^{\circ} \mathrm{C}$. Though the six sharks that left the tagging area did dive to meso- or bathypelagic depths, they spent a relatively small amount of time there. Brunnschweiler \& Sims (2012) hypothesized that dives into the meso- and bathypelagic zones are related to foraging (searching) behaviour, and thus more extensive dives are expected to be more likely to occur in less productive deep oceanic waters. Interpretation is, however, complicated by the fact that sharks may be responding to deeper prey patches that are undetectable by remote sensing methods (Schick et al., 2013). While the observed deeper (V) dives may be linked to searching behaviour, diving can also reduce the cost of travel by whale sharks (Gleiss, Norman \& Wilson, 2011), which would be of similar benefit during movement 
464 afternoon. This pattern has also been observed in whale sharks from the Atlantic (Tyminski et 465 al., 2015) and Western Australia (Wilson et al., 2006). Wilson et al. (2006) suggested that these 466 crepuscular dives may be a means for a visual predator to exploit vertically-migrating prey 467 during a short window of vulnerability. Geomagnetic navigation is also a possible driver, with 468 the sharks plausibly diving to obtain a better 'fix' at around dawn and dusk (Tyminski et al., 469 2015) when magnetic intensity reaches its highest values (Willis et al., 2009).

470

471 All except one shark displayed a reverse diel vertical migration (rDVM; dawn ascent, dusk 472 descent) overall, with deeper mean depth during the hours of darkness. However, 72.7\% of all 473 mesopelagic or deeper dives took place during the day. Little is known of the foraging ecology 474 of adult whale sharks in the Eastern Pacific, or of juvenile sharks away from coastal areas of the 475 GoC. Shark AM1, which had the greatest mean depth and number of dives into the meso- and 476 bathypelagic zones of all the sharks in this study, was the only mature male that was tracked, 477 further indicating the possibility of sex-specific differences in habitat use. The shallow mean 478 depth of most sharks, and orientation towards frontal systems, suggests that surface prey represent an important food source. However, observer-independent dietary studies of southern African whale sharks suggest that they will also forage on deep-water zooplankton and fishes in oceanic waters (Rohner et al., 2013), which corresponds with observations of meso- and bathypelagic diving in that area (Brunnschweiler \& Sims, 2012) that are comparable to those observed in the present study. Similar fatty acid studies on GoC sharks may provide insight on their motivations underlying vertical movements in this region.

While breeding is likely to occur in the GoC region, few adult male whale sharks have been observed during long-term field studies there (Ramírez-Macías, Vázquez-Haikin \& VázquezJuárez, 2012). This was also the case at Darwin Island in the Galapagos (Acuña-Marrero et al., 2014). While genetic results indicate that there is some connectivity between whale shark aggregations within the Indo-Pacific (Vignaud et al., 2014), to date there have been no photographic resightings of $\mathrm{GoC}$ whale sharks in other areas in the Eastern Pacific, such as Cocos Island in Costa Rica (White et al., 2015) or the Galapagos Islands in Ecuador (AcuñaMarrero et al., 2014). While one of the tags deployed on a juvenile shark by Eckert \& Stewart 
494 (2001) is thought to have travelled around 13,000 km across the Pacific, it is now considered

495 unlikely that the tag was still attached to that shark (Brunnschweiler et al., 2009).

496

\section{Conclusion}

498

499

Regular inter-annual resightings of juvenile sharks in the GoC (Ramírez-Macías, Vázquez-

500 Haikin \& Vázquez-Juárez, 2012), coupled with the short-term residency displayed by tagged

501 sharks in this study, suggest that juvenile whale sharks display site fidelity to these coastal waters, at least over the period they remained tracked. While adults may demonstrate some

503 reproductive philopatry (Ramírez-Macías et al., 2007), they appear to be considerably more mobile and primarily oceanic. Conservation efforts for the species should therefore focus on both local scales, where anthropogenic threats to coastal feeding areas could have a disproportionate impact at a population level (Ramírez-Macías, Vázquez-Haikin \& Vázquez-Juárez, 2012), as well as regional threats to breeding populations. Specifically, of the five sites that were regularly used by whale sharks in this study, two - Bahía de La Paz and Banco Gordo - remain unprotected. Our tracking data, together with long-term photo-ID data, demonstrates connectivity between all five sites. Improved protection should be investigated as a potential regional conservation measure, given the international significance of the GoC and surrounding regions to whale shark reproductive ecology.

\section{Acknowledgements}

515 The authors would like to thank Ricardo Vázquez-Juárez for the support in obtaining research 516 authorisations and Alex Antoniou for his advice in tagging whale sharks. Field work was 517 suported by Erick Higuera, Siddharta Velazquez, Paul Ahuja, Felipe Morales, Carlos Aguilera, 518 Paulina Godoy, Alfredo Barroso. The authors thank Christoph Rohner for his comments on the 519 manuscript.

\section{References}


523 Acuña-Marrero D, Jiménez J, Smith F, Doherty Jr PF, Hearn A, Green JR, Paredes-Jarrín J,

524 Salinas-de-León P. 2014. Whale shark (Rhincodon typus) seasonal presence, residence time and

525 habitat use at Darwin Island, Galapagos Marine Reserve. PLoS ONE 9:e115946.

526

527 Afonso P, McGinty N, Machete M. 2014. Dynamics of whale shark occurrence at their fringe

528 oceanic habitat. PLoS ONE 9:e102060.

529

530 Austin D, Bowen WD, Mcmillan JI, Iverson SJ. 2006. Linking movement, diving, and habitat to 531 foraging success in a large marine predator. Ecology 87:3095-3108.

532

533

Block BA, Jonsen ID, Jorgensen SJ, Winship AJ, Shaffer SA, Bograd SJ, Hazen EL, Foley DG, 534 Breed GA, Harrison A-L, Ganong JE, Swithenbank A, Castleton M, Dewar H, Mate BR, Shillinger GL, Schaefer KM, Bensen SR, Weise MJ, Henry RW, Costa DP. 2011. Tracking apex marine predator movements in a dynamic ocean. Nature 475:86-90.

537

538

Borrell A, Aguilar A, Gazo M, Kumarran RP, Cardona L. 2011. Stable isotope profile in whale shark (Rhincodon typus) suggest segregation and dissimilarities in the diet depending on sex and size. Environmental Biology of Fishes 92:559-567.

541 Brunnschweiler JM. 2014. Know your instruments: ensuring depth and temperature data from 542 pop-up satellite archival tags are reported correctly. Journal of Ecosystem \& Ecography S4: 004. 543

Brunnschweiler JM, Baensch H, Pierce SJ, Sims DW. 2009. Deep diving behaviour of a whale shark during long distance movement in the western Indian Ocean. Journal of Fish

546 Biology 74:706-714.

547

548 Brunnschweiler JM, Queiroz N, Sims DW. 2010. Oceans apart? Short-term movements and 549 behaviour of adult bull sharks Carcharhinus leucas in Atlantic and Pacific Oceans determined 550 from pop-off satellite archival tagging. Journal of Fish Biology 77:1343-1358. 
552 Brunnschweiler JM, Sims DW. 2012. Diel oscillations in whale shark vertical movements

553 associated with meso- and bathypelagic diving. American Fisheries Society Symposium 76:457554469.

555

556 Clark E, Nelson DR. 1997. Young whale sharks, Rhincodon typus, feeding on a copepod bloom 557 near La Paz, Mexico. Environmental Biology of Fishes 50:63-73.

558

559 Cochran JEM, Hardenstine RS, Braun CD, Skomal GB, Thorrold SR, Xu K, Genton MG, 560 Berumen ML. 2016. Population structure of a whale shark Rhincodon typus aggregation in the 561 Red Sea. Journal of Fish Biology 89:1570-1582.

562

563 Croll DA, Newton KM, Weng K, Galván-Magaña F, O’Sullivan J, Dewar H. 2012. Movement 564 and habitat use by the spine-tail devil ray in the Eastern Pacific Ocean. Marine Ecology Progress 565 Series 465:193-200.

566

567

Eckert SA, Stewart BS. 2001. Telemetry and satellite tracking of whale sharks, Rhincodon typus 568 in the Sea of Cortez, Mexico, and the north Pacific Ocean. Environmental Biology of Fishes $56960: 299-308$.

570

571 Gleiss AC, Norman B, Wilson RP. 2011. Moved by that sinking feeling: variable diving 572 geometry underlies movement strategies in whale sharks. Functional Ecology 25:595-607. 573

574 Gunn JS, Stevens JD, Davis TLO, Norman BM. 1999. Observations on the short-term 575 movements and behaviour of whale sharks (Rhincodon typus) at Ningaloo Reef, Western 576 Australia. Marine Biology 135:553-559.

577

578 Hacohen-Domené A, Galván-Magaña F, Ketchum-Mejia J. 2006. Abundance of whale shark 579 (Rhincodon typus) preferred prey species in the southern Gulf of California, Mexico. Cybium 30 580 suppl:99-102. 
582 Harrell FE, Lee KL, Califf RM, Pryor DB, Rosati RA. 1984. Regression modelling strategies for 583 improved prognostic prediction. Statistics in Medicine 3:143-152.

584

585 Hearn AR, Green JR, Espinoza E, Peñaherrera C, Acuña D, Klimley AP. 2013. Simple criteria to 586 determine detachment point of towed satellite tags provide first evidence of return migrations of 587 whale sharks (Rhincodon typus) at the Galapagos Islands, Ecuador. Animal Biotelemetry 1:11. 588 female whale sharks make long-distance movements past Darwin Island (Galapagos, Ecuador) in 591 the Eastern Tropical Pacific. Marine Biology 163:214.

592

593

Hueter RE, Tyminski JP, de la Parra R. 2013. Horizontal movements, migration patterns, and 594 population structure of whale sharks in the Gulf of Mexico and northwestern Caribbean Sea. PLoS ONE 8:e71883.

596

Ketchum JT, Galván-Magaña F, Klimley AP. 2013. Segregation and foraging ecology of whale 598 sharks, Rhincodon typus, in the southwestern Gulf of California. Environmental Biology of 599 Fishes 96:779-795.

600

601

Marshall AD, Pierce SJ. 2012. The use and abuse of photographic identification in sharks and 602 rays. Journal of Fish Biology 80:1361-1379.

603

Miller PI, Scales KL, Ingram SN, Southall EJ, Sims DW. 2015. Basking sharks and 605 oceanographic fronts: quantifying associations in the north-east Atlantic. Functional 606 Ecology 29:1099-1109.

607

608 Nelson JD, Eckert SA. 2007. Foraging ecology of whale sharks (Rhincodon typus) within Bahía 609 de Los Angeles, Baja California Norte, México. Fisheries Research 84:47-64.

610

611 Norman BM, Stevens JD. 2007. Size and maturity status of the whale shark (Rhincodon typus) at 612 Ningaloo Reef in Western Australia. Fisheries Research 84:81-86. 
613

614 Pade NG, Queiroz N, Humphries NE, Witt MJ, Jones CS, Noble LR, Sims DW. 2009. First

615 results from satellite-linked archival tagging of porbeagle shark, Lamna nasus: Area fidelity,

616 wider-scale movements and plasticity in diel depth changes. Journal of Experimental Marine

617 Biology and Ecology 370:64-74.

618

619 Pierce SJ, Norman B. 2016. Rhincodon typus. The IUCN Red List of Threatened Species

620 2016:e.T19488A2365291. Available at http://dx.doi.org/10.2305/IUCN.UK.2016-

621 1.RLTS.T19488A2365291.en (accessed 28 January 2017).

622

623 Queiroz N, Humphries NE, Mucientes G, Hammerschlag N, Lima FP, Scales KL, Miller PI, 624 Sousa LL, Seabra R, Sims DW. 2016. Ocean-wide tracking of pelagic sharks reveals extent of 625 overlap with longline fishing hotspots. Proceedings of the National Academy of Sciences USA $626113: 1582-1587$.

627

628

Ramírez-Macías D, Vázquez-Juárez R, Galván-Magaña F, Munguía-Vega A. 2007. Variations of 629 the mitochondrial control region sequence in whale sharks (Rhincodon typus) from the Gulf of 630 California, Mexico. Fisheries Research 84:87-95.

631

632 Ramírez-Macías D, Vázquez-Haikin A, Vázquez-Juárez R. 2012. Whale shark Rhincodon typus 633 populations along the west coast of the Gulf of California and implications for management.

634 Endangered Species Research 18:115-128.

635

636 Robinson DP, Jaidah MY, Jabado RW, Lee-Brooks K, Nour El-Din NM, Al Malki AA, Elmeer 637 K, McCormick PA, Henderson AC, Pierce SJ, Ormond RFG. 2013. Whale sharks, Rhincodon 638 typus, aggregate around offshore platforms in Qatari waters of the Arabian Gulf to feed on fish 639 spawn. PLoS ONE 8:e58255.

640

641 Robinson DP, Jaidah MY, Bach S, Lee K, Jabado RW, Rohner CA, March A, Caprodossi S, 642 Henderson AC, Mair JM, Ormond R, Pierce SJ. 2016. Population structure, abundance and 643 movement of whale sharks in the Arabian Gulf and the Gulf of Oman. PLoS ONE 11:e0158593. 
645 Robinson RA, Crick HQP, Learmonth JA, Maclean IMD, Thomas CD, Bairlein F, Forchhammer 646 MC, Francis CM, Gill JA, Godley BJ, Harwood J, Hays GC, Huntley B, Hutson AM, Pierce GJ, 647 Rehfisch MM, Sims DW, Begoña Santos M, Sparks TH, Stroud DA, Visser ME. 2009.

648 Travelling through a warming world: climate change and migratory species. Endangered Species 649 Research 7:87-99.

650

651 Rohner CA, Couturier LIE, Richardson AJ, Pierce SJ, Prebble CEM, Gibbons MJ, Nichols PD.

652 2013. Diet of whale sharks Rhincodon typus inferred from stomach content and signature fatty 653 acid analyses. Marine Ecology Progress Series 493:219-235.

Rohner CA, Armstrong AJ, Pierce SJ, Prebble CEM, Cagua EF, Cochran JEM, Berumen ML, 656 Richardson AJ. 2015a. Whale sharks target dense patches of sergestid shrimp off Tanzania.

657 Journal of Plankton Research 37:352-362.

658

Rohner CA, Richardson AJ, Prebble CEM, Marshall AD, Bennett MB, Weeks SJ, Cliff G, 660 Wintner SP, Pierce SJ. 2015b. Laser photogrammetry improves size and demographic estimates 661 for whale sharks. PeerJ 3:e886.

662

Rowat D, Brooks KS. 2012. A review of the biology, fisheries and conservation of the whale 664 shark Rhincodon typus. Journal of Fish Biology 80:1019-1056.

665

Rowat D, Gore MA, Baloch BB, Islam Z, Ahmad E, Ali QM, Culloch RM, Hameed S, Hasnain 667 SA, Hussain B, Kiani S, Siddiqui J, Ormond RF, Henn N, Khan M. 2008. New records of 668 neonatal and juvenile whale sharks (Rhincodon typus) from the Indian Ocean. Environmental 669 Biology of Fishes 82:215-219.

670

671 Schick RS, Roberts JJ, Eckert SA, Halpin PN, Bailey H, Chai F, Shi L, Clark JS. 2013. Pelagic 672 movements of Pacific leatherback turtles (Dermochelys coriaea) highlight the role of prey and 673 ocean currents. Movement Ecology 1:11. 
675 Sequeira AMM, Mellin C, Meekan MG, Sims DW, Bradshaw CJA. 2013. Inferred global

676 connectivity of whale shark Rhincodon typus populations. Journal of Fish Biology 82:367-389.

677

678 Sims DW. 2000. Filter-feeding and cruising swimming speeds of basking sharks compared with 679 optimal models: they filter-feed slower than predicted for their size. Journal of Experimental 680 Marine Biology and Ecology 249:65-76.

681

682 Sims DW. 2008. Sieving a living: A review of the biology, ecology and conservation status of 683 the plankton-feeding basking shark Cetorhinus maximus. Advances in Marine Biology 54:171684220.

685

686 Sims DW. 2010. Tracking and analysis techniques for understanding free-ranging shark 687 movements and behaviour. In Carrier J, Heithaus M, Musick J, eds. Biology of Sharks and their 688 Relatives, Vol. II Biodiversity, Adaptive Physiology, and Conservation. Boca Raton, USA: CRC 689 Press, 351-392.

690

Swets JA. 1988. Measuring the accuracy of diagnostic systems. Science 240:1285-1293.

692

693

Tyminski JP, de la Parra-Venegas R, González Cano J, Hueter RE. 2015. Vertical movements

694 and patterns in diving behavior of whale sharks as revealed by pop-up satellite tags in the eastern 695 Gulf of Mexico. PLoS ONE 10:e142156.

696

697

Venables WN, Ripley BD. 2002. Modern Applied Statistics with S. New York: Springer. 698

Vignaud TM, Maynard JA, Leblois R, Meekan MG, Vázquez-Juárez R, Ramírez-Macías D, populations of whale sharks among ocean basins and evidence for their historic rise and recent 702 decline. Molecular Ecology 23:2590-2601. 
704 White ER, Myers MC, Flemming JM, Baum JK. 2015. Shifting elasmobranch community 705 assemblage at Cocos Island-an isolated marine protected area. Conservation Biology 29:11867061197.

707

708 Wilkinson T, Wiken E, Bezaury-Creel J, Hourigan T, Agardy T, Herrmann H, Janishevski L, 709 Madden C, Morgan L, Padilla M. 2009. Marine Ecoregions of North America. Commission for 710 Environmental Cooperation. Montreal, Canada.

711

712 Willis J, Phillips J, Muheim R, Diego-Rasilla FJ, Hobday AJ. 2009. Spike dives of juvenile 713 southern bluefin tuna (Thunnus maccoyii): a navigational role? Behavioral Ecology and 714 Sociobiology 64:57-68.

715

716

717

Wilson SG, Polovina JJ, Stewart BS, Meekan MG. 2006. Movements of whale sharks 718 (Rhincodon typus) tagged at Ningaloo Reef, Western Australia. Marine Biology 148:1157-1166.

Wolfson FH. 1983. Records of seven juveniles of the whale shark, Rhiniodon typus. Journal of

721

722 Zuur AF, Ieno EN, Walker NJ, Saveliev AA, Smith GM. 2009. Mixed effects models and 723 extensions in ecology with $R$. New York: Springer. 
Figure 1

Study area and geolocated tracks of whale sharks.

(A) Map of the study area in the north-east Pacific showing main locations mention in the manuscript, BG = Banco Gordo; (B) Geolocated tracks of whale sharks in the north-east Pacific Ocean overlaid on bathymetry; stars denote pop-off locations and red square the area enlarged in A.

A

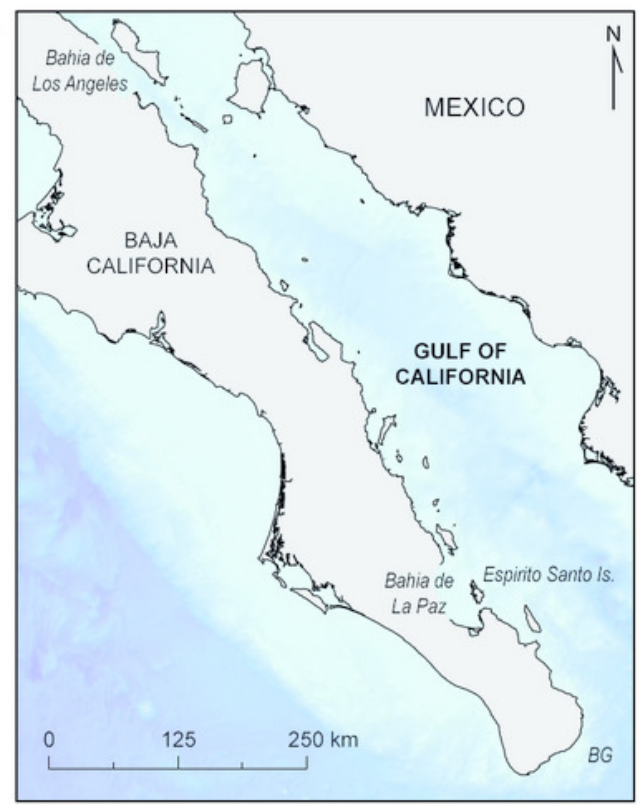

B

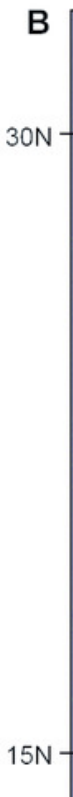

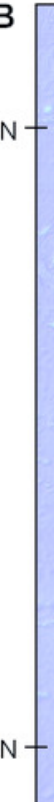

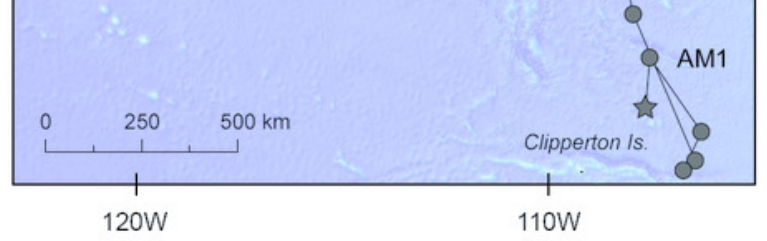

O AF4

- AM1

- $\mathrm{AF} 3$

O JF1

- JM2

- AF2

- AF1

O JM1 


\section{Figure 2}

Major areas of residency.

Kernel density plot (estimated using the coastline as a barrier) showing the two major areas of prolonged residency (in number of days), one inside the Gulf of California and another offshore; dashed line represents $95 \%$ isopleth.

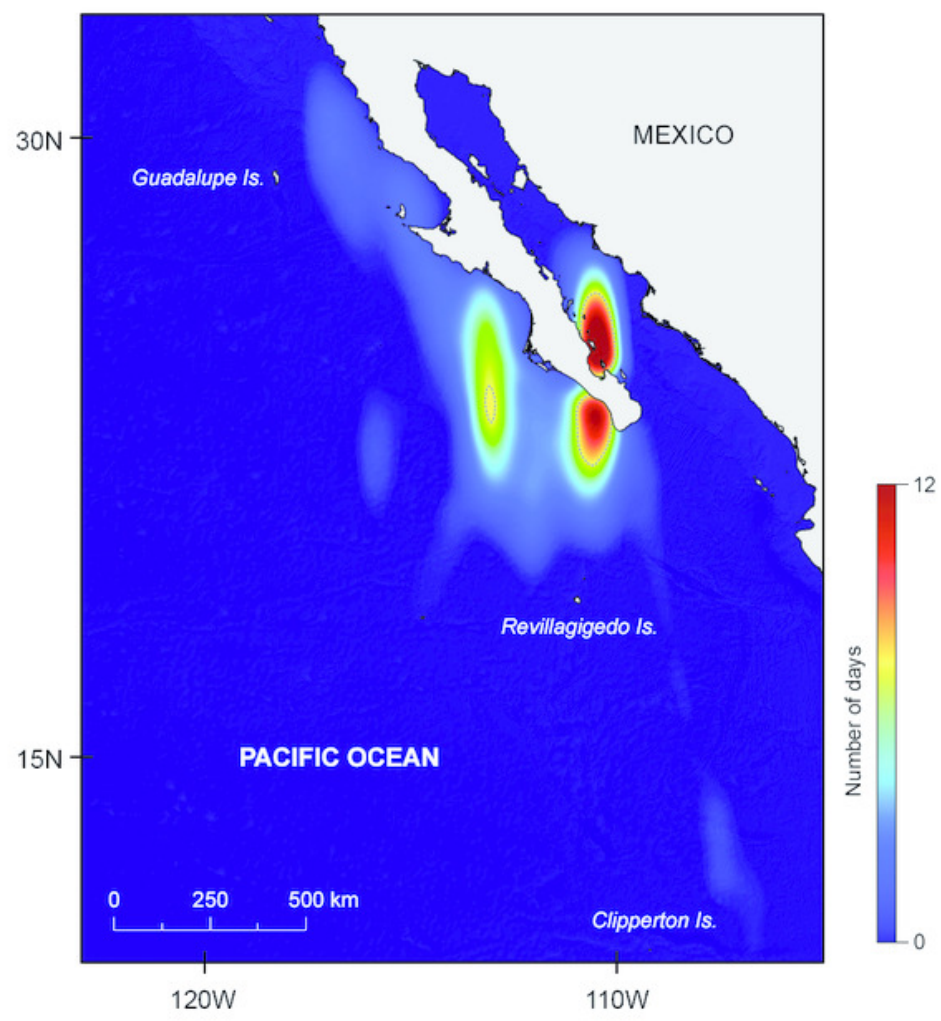




\section{Figure 3}

Diving activity.

Time-depth series recorded by tags attached to whale sharks leaving Bahía de La Paz (tagging area) at large scale. Dots denote daily maximum depths (epipelagic: $0 \mathrm{~m},<200 \mathrm{~m}$ (yellow); mesopelagic: >200 m, <1000 m (green); bathypelagic: >1000 m (red) zones). 


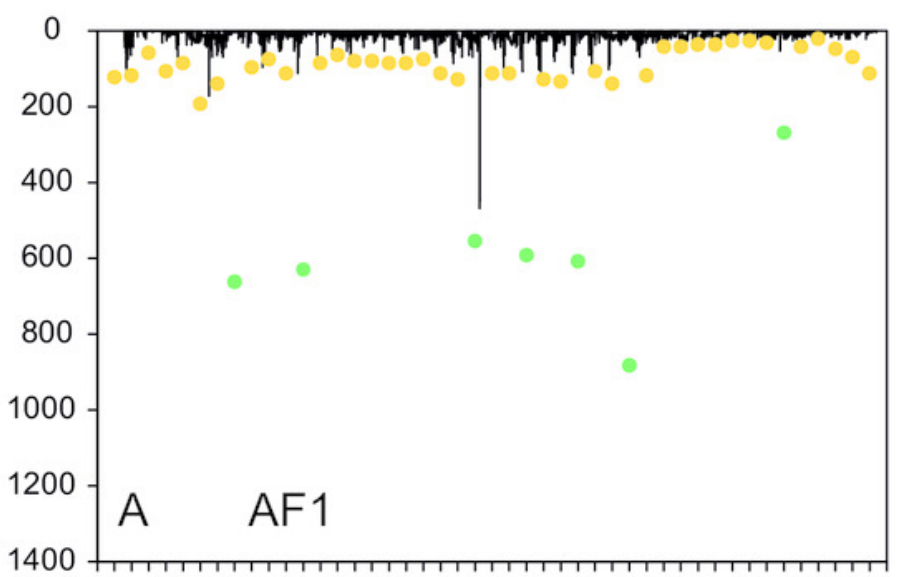

23 May to 6 July 2009

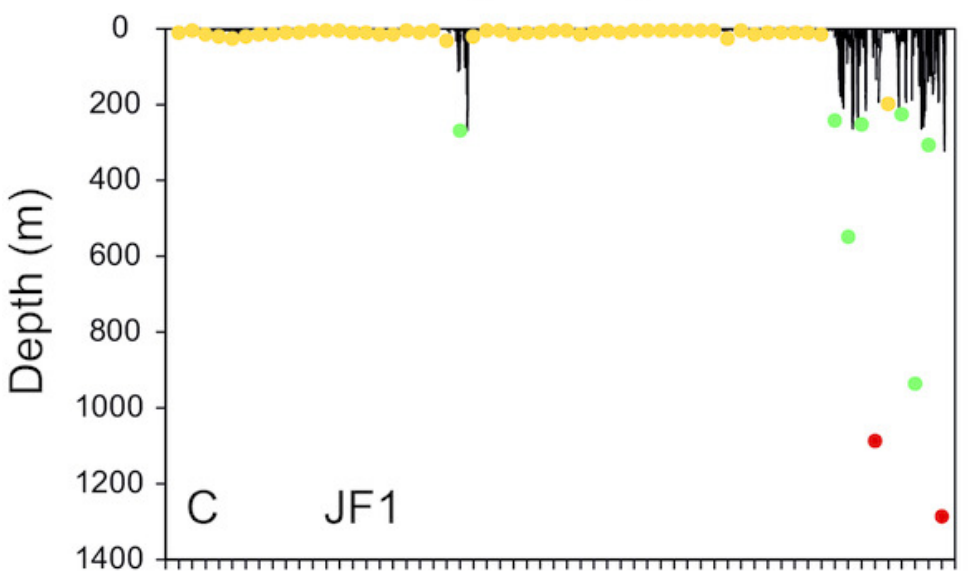

13 March to 19 May 2010

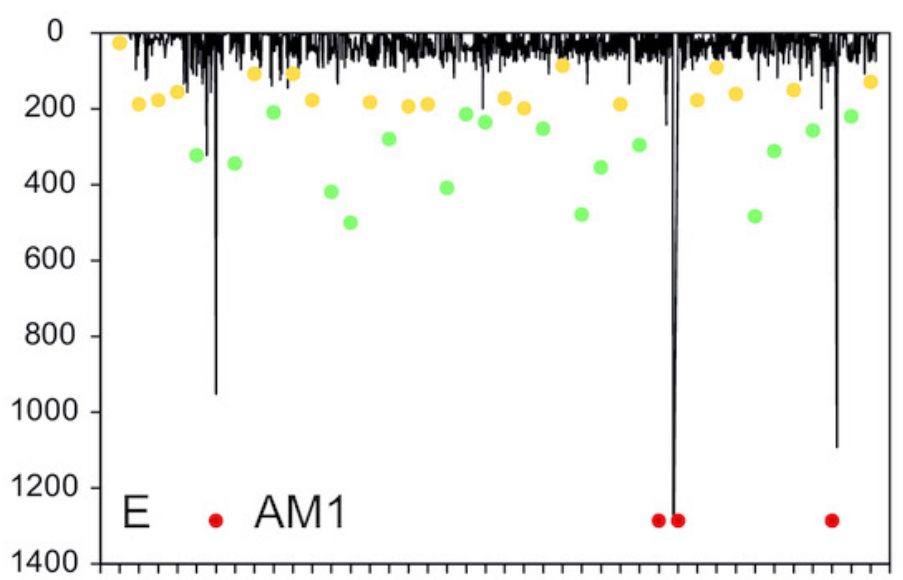

13 July to 21 August 2010

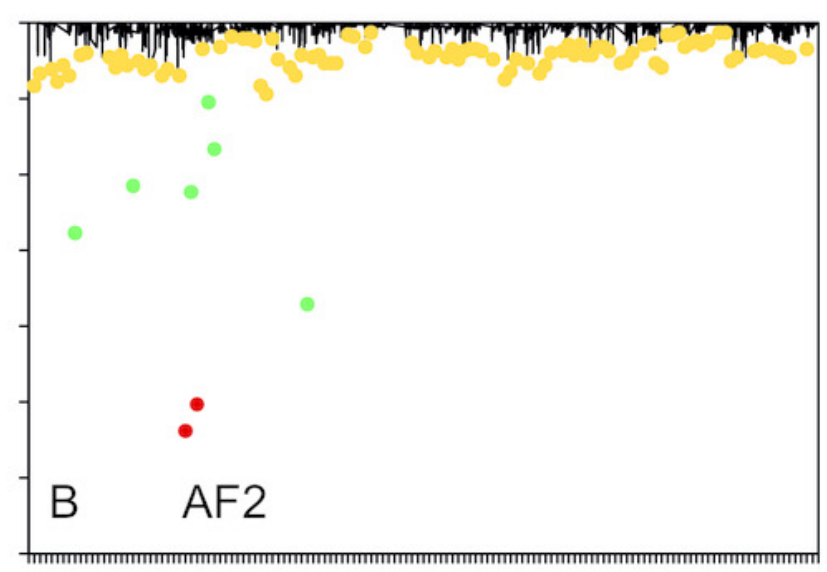

24 May to 5 October 2009

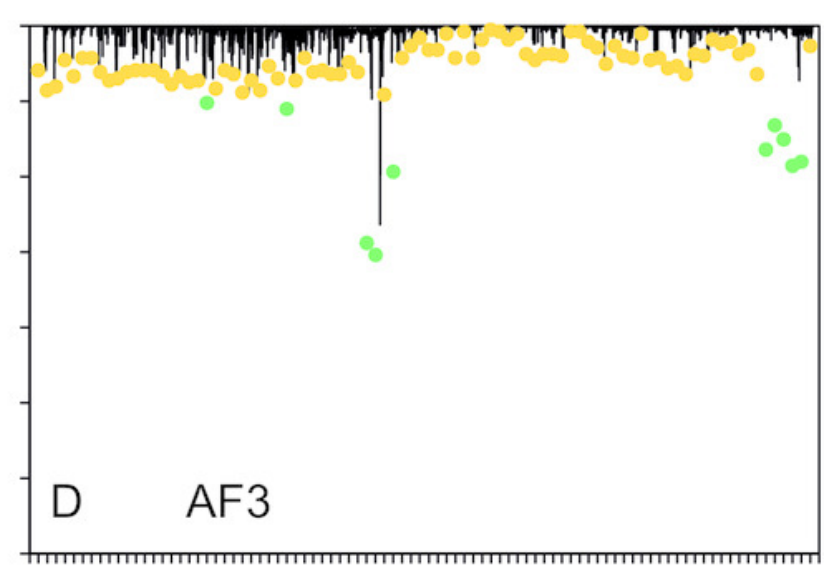

29 June to 24 September 2010

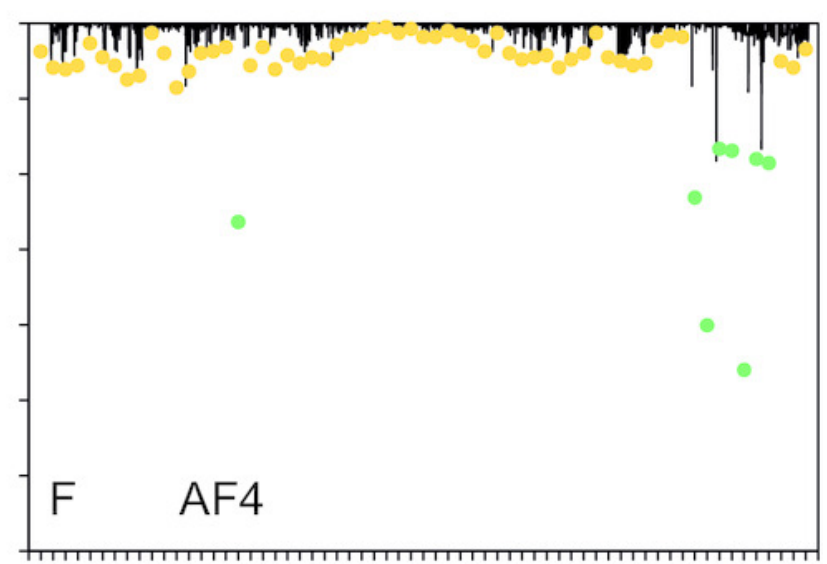

13 July to 13 September 2010 


\section{Figure 4}

Meso- and bathypelagic diving.

Percent archived depth recordings in the meso- and bathypelagic zones at hourly intervals from all whale sharks leaving Bahía de La Paz (tagging area) at large scale. Note that deltalimited dives were also included. The total number of depth recordings was 154: mesopelagic $(M$; green $=43)$, bathypelagic $(B$; red $=4)$ and delta limited $(D L ;$ dark grey $=107)$. Grey shaded areas denote night.

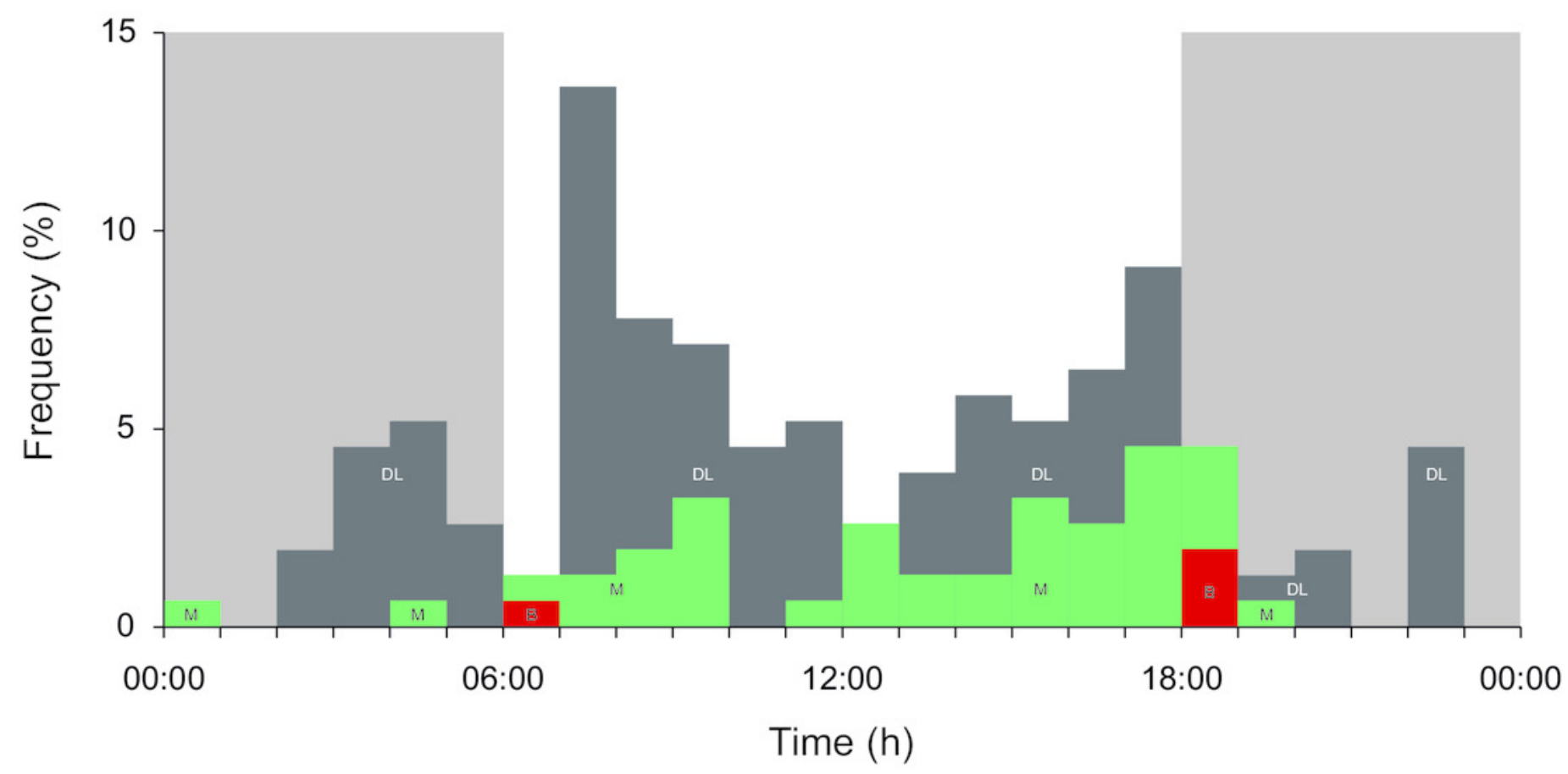




\section{Figure 5}

Mesopelagic dives.

(A) Isolated mesopelagic (green) V-dive performed by whale shark AF1 on 13 June 2009,

06:30-07:00; (B) two mesopelagic V-dives in series performed by whale shark JF1 on 3 April 2010, 12:45-14:45; (C) mesopelagic U-dive performed by whale shark JF1 on 7 May 2010, 13:45-18:45; examples of a (D) mesopelagic and ( $E$ and F) the only two bathypelagic (red) dive profiles that could not be assigned with confidence to any of the diving patterns described in Gleiss, Norman \& Wilson (2011) due to missing archived data points ( $E$ and F), and delta limited dives and ascents (grey dots in (C-F); the whale shark was deeper (downward-pointing arrows) or less deep (upward-pointing arrows) than the archived value indicates; see Brunnschweiler (2014) for details). 

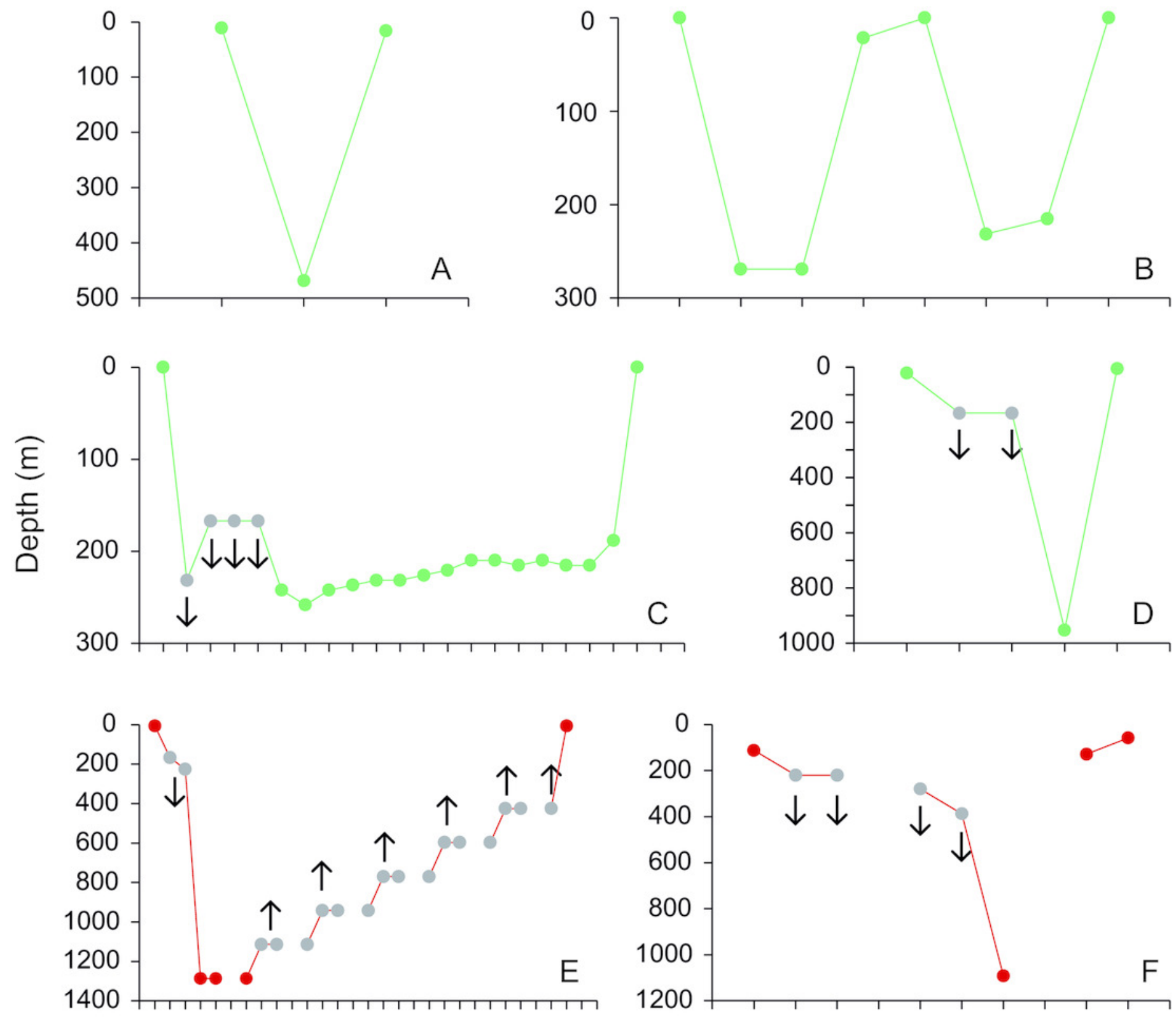

Time interval (15 min) 


\section{Table $\mathbf{1}$ (on next page)}

Tagging details and performance of PSATs attached to whale sharks in the Gulf of California.

Set pop-off interval is the programmed time PSATs were schedule to report data after deployment. * denotes PSATs attached to whale sharks (WS) that did not uplink to the Argos satellite system, $\mathrm{J}=$ juvenile, $\mathrm{A}=$ adult, $\mathrm{M}=$ male, $\mathrm{F}=$ female, $\mathrm{cP}=$ constant pressure, $\mathrm{td}=$ too deep emergency release, ukn $=$ unknown, $\mathrm{DAL}=$ days-at-liberty, $\mathrm{nr}=$ nonreporting. 
Table 1 Tagging details and performance of PSATs attached to whale sharks in the Gulf of California. Set pop-off interval is the programmed time PSATs were schedule to report data after deployment. * denotes PSATs attached to whale sharks (WS) that did not uplink to the Argos satellite system, $\mathrm{J}=$ juvenile, A = adult, $\mathrm{M}=$ male, $\mathrm{F}=$ female, $\mathrm{cp}=$ constant pressure, $\mathrm{td}=$ too deep emergency release, $\mathrm{ukn}=$ unknown, $\mathrm{DAL}=$ days-at-liberty, $\mathrm{nr}=$ nonreporting.

\begin{tabular}{|c|c|c|c|c|c|c|c|c|c|c|c|}
\hline Shark ID & Sex & $\begin{array}{l}\text { Estimated } \\
\text { length }(\mathrm{m})\end{array}$ & $\begin{array}{l}\text { Maturity } \\
\text { status }\end{array}$ & Tagging date & $\begin{array}{l}\text { Set pop-off } \\
\text { interval } \\
\text { (days) }\end{array}$ & Pop-off date & Pop-off area & $\begin{array}{l}\text { Pop- } \\
\text { off } \\
\text { reason }\end{array}$ & DAL & $\begin{array}{l}\text { Pressure data } \\
\text { availablea/used }^{\text {b }} \\
\text { for analysis (\%) } \\
\end{array}$ & $\begin{array}{l}\text { Temperature data } \\
\text { available } / \text { used }^{b} \\
\text { for analysis ( } \%)\end{array}$ \\
\hline JM1 & M & 7 & juvenile & $\begin{array}{l}2008 \\
19 \text { November } \\
2009\end{array}$ & 274 & 13 December & Bahía de La Paz & $\mathrm{cp}$ & 25 & $100 / 100$ & $100 / 100$ \\
\hline *WS2 & M & 7 & juvenile & 17 January & 274 & & & & $\mathrm{nr}$ & & \\
\hline *WS3 & M & 7 & juvenile & 17 January & 274 & & & & $\mathrm{nr}$ & & \\
\hline *WS4 & $\mathrm{F}$ & 12 & pregnant & 23 May & 365 & & & & $\mathrm{nr}$ & & \\
\hline AF1 & $\mathrm{F}$ & 12 & pregnant & 23 May & 365 & 6 July & offshore & $\mathrm{cp}$ & 44 & $100 / 99.7$ & 98.9/95.9 \\
\hline AF2 & $\mathrm{F}$ & 10.5 & pregnant & 24 May & 365 & $5^{c}$ October & offshore & $\mathrm{ukn}^{\mathrm{d}}$ & 134 & $30 / 30$ & $30.4 / 29.4$ \\
\hline *WS7 & $\mathrm{F}$ & 11.5 & pregnant & $\begin{array}{l}26 \text { May } \\
2010\end{array}$ & 365 & & & & $\mathrm{nr}$ & & \\
\hline JM2 & M & 7 & juvenile & $10 \mathrm{March}$ & 274 & 23 March & Bahía de La Paz & $\mathrm{cp}$ & 14 & $100 / 100$ & $100 / 100$ \\
\hline *WS9 & M & 5 & juvenile & 11 March & 365 & & & & $\mathrm{nr}$ & & \\
\hline $\mathrm{JF} 1$ & $\mathrm{~F}$ & 5 & juvenile & 13 March & 365 & 9 May & Bahía de Los Angeles & $\mathrm{td}$ & 58 & $99.5 / 98.1$ & $99.9 / 97.5$ \\
\hline *WS11 & $\mathrm{F}$ & 12 & pregnant & 2 June & 365 & & & & $\mathrm{nr}$ & & \\
\hline *WS12 & $\mathrm{F}$ & 11 & pregnant & 23 June & 365 & & & & $\mathrm{nr}$ & & \\
\hline AF3 & $\mathrm{F}$ & 11.5 & pregnant & 29 June & 365 & 24 September & offshore & ukn & 88 & $98.4 / 98.2$ & $96.5 / 92.5$ \\
\hline AM1 & $\mathrm{M}$ & 9 & adult & 13 July & 365 & 21 August & offshore & $\mathrm{td}^{\mathrm{e}}$ & 40 & $75.9 / 74.3$ & $76.9 / 59.1$ \\
\hline AF4 & $\mathrm{F}$ & 11 & pregnant & $\begin{array}{l}13 \text { July } \\
2011\end{array}$ & 365 & 13 September & offshore & ukn & 63 & $97.2 / 96.9$ & $95.9 / 92.9$ \\
\hline *WS16 & M & 6 & juvenile & $\begin{array}{l}16 \text { February } \\
2012\end{array}$ & 274 & & & & $\mathrm{nr}$ & & \\
\hline *WS17 & $\mathrm{F}$ & 12 & pregnant & 8 May & 365 & & & & $\mathrm{nr}$ & & \\
\hline
\end{tabular}

${ }^{a}$ Including delta limited values

${ }^{\mathrm{b}}$ Excluding delta limited values

${ }^{\mathrm{c}}$ The exact pop-off date is unknown. Constant $0 \mathrm{~m}$ depth readings were archived as of 11 October. No archived depth data were transmitted for after 5 October, so this date was considered pop-off date although it is possible that the tag stayed on for more days

$\mathrm{d}$ The constant pressure release mechanism was activated on 21 September, but the PSAT stayed attached to the whale shark until at least 5 October. It is possible that the popoff wire did not fully corrode and it took some time before the PSAT was able to break the weakened wire

${ }^{\mathrm{e}}$ The too deep emergency release mechanism was activated on 11 August, but the PSAT stayed attached to the whale shark until 21 August when it detached and came to the surface. It is possible that the popoff wire did not fully corrode and it took some time before the PSAT was able to break the weakened wire 


\section{Table 2 (on next page)}

Resighting history of eight whale sharks. 
Table 2 Resighting history of eight whale sharks.

\begin{tabular}{|c|c|c|c|c|}
\hline $\begin{array}{l}\text { Shark } \\
\text { ID }\end{array}$ & $\begin{array}{l}\text { Number of } \\
\text { resightings }\end{array}$ & $\begin{array}{l}\text { Location of } \\
\text { resighting(s) }\end{array}$ & $\begin{array}{l}\text { Min/max time (days) after } \\
\text { tagging date }\end{array}$ & Remarks \\
\hline JM1 & 1 & Bahía de La Paz & $28 / 28$ & Monofilament tether still in place. \\
\hline JM2 & 3 & Bahía de La Paz & $1 / 16$ & $\begin{array}{l}\text { PSAT attached at first two resightings; only monofilament tether at last } \\
\text { resighting. }\end{array}$ \\
\hline $\mathrm{JF} 1$ & 4 & Bahía de La Paz & $9 / 272$ & $\begin{array}{l}\text { Resighted with PSAT attached 9,26 and } 28 \text { days after tagging; without } \\
\text { PSAT at last resighting. }\end{array}$ \\
\hline WS2 & 4 & Bahía de La Paz & $12 / 53$ & $\begin{array}{l}\text { PSAT attached at first three resightings; only monofilament tether at last } \\
\text { resighting. }\end{array}$ \\
\hline WS3 & 15 & Bahía de La Paz & $3 / 292$ & $\begin{array}{l}\text { Resighted } 14 \text { times with the PSAT attached until } 65 \text { days after tagging; } \\
\text { only monofilament tether at last resighting. }\end{array}$ \\
\hline WS9 & 2 & Bahía de La Paz & $21 / 286$ & First resighting with, last resightin without PSAT attached. \\
\hline WS16 & 1 & $\begin{array}{l}\text { Bahía de Los } \\
\text { Angeles }\end{array}$ & 178/178 & Without PSAT attached. \\
\hline WS17 & 1 & $\begin{array}{l}\text { Revillagigedo } \\
\text { Islands }\end{array}$ & 198/198 & Without PSAT attached. \\
\hline
\end{tabular}




\section{Table 3(on next page)}

Results of the GLMM model.

Model results are given in the following format: $\beta \pm S D, P, C$-index, where $\beta$ is a measure of the slope of the relationship and C-index the concordance index between predicted and observed responses; * denotes significant relationship. 
1 Table 3. Results of the GLMM model; model results are given in the following format: $\beta \pm \mathrm{SD}, \mathrm{P}, \mathrm{C}$-index, where $\beta$ is a measure of the slope of the relationship 2 and $\mathrm{C}$-index the concordance index between predicted and observed responses; ${ }^{*}$ denotes significant relationship

\begin{tabular}{lll}
\hline Variable & $\beta \pm \mathrm{SD}$ & $P$ \\
\hline Chlorophyll $a$ concentration & $-0.28 \pm 0.15$ & 0.06 \\
SST & $-0.27 \pm 0.03$ & $<0.001^{*}$ \\
SST gradients & $25.57 \pm 7.14$ & $<0.001^{*}$ \\
\hline
\end{tabular}

3 


\section{Table 4 (on next page)}

Summary statistics.

Depth $(\mathrm{m})$ and temperature $\left({ }^{\circ} \mathrm{C}\right)$ summary statistics for whale sharks tagged in the Gulf of California. 
1 Table 4 Depth (m) and temperature $\left({ }^{\circ} \mathrm{C}\right)$ summary statistics for whale sharks tagged in the Gulf of California.

\begin{tabular}{|c|c|c|c|c|c|c|c|c|c|}
\hline \multirow[b]{2}{*}{ Shark ID } & \multicolumn{7}{|l|}{ Depth (m) } & \multicolumn{2}{|c|}{ Temperature $\left({ }^{\circ} \mathrm{C}\right)$} \\
\hline & Mean \pm SD & Median & $\begin{array}{l}\text { Mean } \pm \text { SD } \\
\text { day }\end{array}$ & $\begin{array}{l}\text { Median } \\
\text { day }\end{array}$ & $\begin{array}{l}\text { Mean } \pm \text { SD } \\
\text { night }\end{array}$ & $\begin{array}{l}\text { Median } \\
\text { night }\end{array}$ & Maximum & Mean \pm SD & Median \\
\hline JM1 & $3.9 \pm 4.8$ & 5.4 & $3.7 \pm 4.5$ & 5.4 & $4.2 \pm 5.1$ & 5.4 & 32.3 & $25.48 \pm 0.73$ & 25.48 \\
\hline AF1 & $9 \pm 14.6$ & 5.4 & $7.5 \pm 16.4$ & 5.4 & $10.6 \pm 12.5$ & 5.4 & 882.3 & $21.64 \pm 1.52$ & 21.70 \\
\hline AF2 & $13.4 \pm 12.6$ & 10.8 & $12.5 \pm 12.7$ & 10.8 & $14.4 \pm 12.4$ & 10.8 & 1076 & $22.17 \pm 1.74$ & 22.20 \\
\hline JM2 & $1.1 \pm 2.7$ & 0 & $0.5 \pm 1.9$ & 0 & $1.7 \pm 3.2$ & 0 & 21.5 & $22.29 \pm 0.49$ & 22.20 \\
\hline JF1 & $6 \pm 27.4$ & 0 & $8.1 \pm 34.7$ & 0 & $3.9 \pm 17.3$ & 0 & 1285.8 & $22.44 \pm 1.77$ & 22.71 \\
\hline AF3 & $6.3 \pm 16$ & 0 & $4.9 \pm 16.1$ & 0 & $7.8 \pm 15.8$ & 0 & 607.9 & $22.62 \pm 1.67$ & 22.71 \\
\hline AM1 & $29.4 \pm 57.2$ & 21.5 & $25.1 \pm 41.9$ & 5.4 & $33.1 \pm 68.4$ & 26.9 & 1285.8 & $24.53 \pm 3.86$ & 25.66 \\
\hline AF4 & $7.7 \pm 16.4$ & 0 & $6.3 \pm 15.3$ & 0 & $9.1 \pm 17.2$ & 5.4 & 919 & $23.58 \pm 1.99$ & 23.73 \\
\hline
\end{tabular}

4 